\title{
Spatial and temporal variability of carbon dioxide and methane fluxes in an Amazonian estuary
}

\begin{abstract}
Despite scarce information in the Amazon regions, aquatic environments in tropical mangroves are important carbon deposits, and little is known about the exchange of carbon dioxide $\left(\mathrm{CO}_{2}\right)$ and methane $\left(\mathrm{CH}_{4}\right)$ with the atmosphere. We used a dynamic floating chamber to measure $\mathrm{CO}_{2}$ and $\mathrm{CH}_{4}$ fluxes in different aquatic surfaces (river, bore, and stream) on a monthly basis. Water physical-chemical parameters were also measured. Daily tide level variations have influenced $\mathrm{CH}_{4}$ flux in the rainy season. The water surface in the studied Amazonian estuary was a source of $\mathrm{CO}_{2}$ and $\mathrm{CH}_{4}$ to the atmosphere, and the $\mathrm{CO}_{2}$ output was much greater in the rainy season. Their seasonal flux did not present differences among rivers, bore, and streams in the two assessed seasons, but there was monthly variation in their fluxes, which were much higher than in other studies carried out in the tropics (mean production of $\left.3.35 \mathrm{Gg} \mathrm{CO}_{2}-\mathrm{e} \mathrm{y}^{-1}\right)$.
\end{abstract}

Keywords: $\mathrm{CO}_{2}$ flux, $\mathrm{CH}_{4}$ flux, mangrove ecosystems, environmental parameters, Amazon
Volume 5 Issue 6 - 202I

Saúl Edgardo Martínez Castellón,' José Henrique Cattanio,' José Francisco Berrêdo, ${ }^{2}$ Marcelo Rollnic, ${ }^{3}$ Vania Neu, ${ }^{4}$ Maridalva Ribeiro ${ }^{5}$

'Graduate Program in Environmental Sciences, Federal University of Pará, Belém, Brazil

${ }^{2}$ Graduate Program in Environmental Sciences, Paraense Emílio Goeldi Museum, Belém, Brazil

${ }^{3}$ Marine Environmental Monitoring Research Laboratory, Federal University of Pará, Belém, Brazil

${ }^{4}$ Socio-Environmental and Water Resources Institute, Federal Rural University of Amazon, Belém, Brazil

${ }^{5}$ Department of Earth Sciences and Ecology, Paraense Emílio Goeldi Museum, Belém, Brazil

Correspondence: José Henrique Cattanio, Graduate Program in Environmental Sciences, Federal University of Pará, Belém, Brazil,Email cattanio@ufpa.br

Received: June 28, 202I | Published: December 29, 202 I

\section{Introduction}

In this paper, we will try to focus on the scarce information related to the tropical mangrove environment. Mangroves are dynamic ecosystems that, in relation to the carbon cycle, make a connection between terrestrial, fluvial, oceanic, and atmospheric compartments. ${ }^{1}$ The estuarine area in northern Brazil has the largest coastal mangrove in the world, with an extension of approximately $1,200 \mathrm{~km}^{2}$ Amazonian mangrove presents an extensive channels network, where streams are formed by the macro-tides movement, and rivers are interconnected by bores. Mangroves are highly productive ecosystems that store significant amounts of carbon (blue carbon) at global level, and it explains their importance for the coastal carbon biogeochemical cycle. $^{3}$

Between $46 \%$ to $100 \%$ of organic carbon (DOC) and inorganic carbon (DIC) dissolved in waters of mangrove streams comes from the porewater, with variations between seasons and tidal amplitudes. ${ }^{4}$ Underground inorganic carbon is partially exported to adjacent water courses due to the (re)circulation of tidal water, which involves infiltration of sediments during high tides and porewater discharge during low tides via advection., ${ }^{5,6}$ It is established that most of the carbon being tidally exported from mangroves is DIC, a result of organic matter mineralization and the porewater inlet. The inorganic materials come from groundwater (rich in dissolved carbon) transported by rivers, from carbon coming from humid zones such as coastal beach vegetation, mangrove forest and the ocean. ${ }^{7,8}$ Due to the high turbidity, supply of particulate organic material (POC), reducing environment, intense change in salinity, and low export of labile organic carbon, estuarine waters act as a net source of $\mathrm{CO}_{2}$ and $\mathrm{CH}_{4}$ to the atmosphere. ${ }^{9}$ However, mangrove forests are natural carbon sinks that remove $\mathrm{CO}_{2}$ from the atmosphere and store it in their biomass for decades. ${ }^{10}$
The global estimate for $\mathrm{CO}_{2}$ emissions in tropical estuaries (between latitudes 0 to $23.5^{\circ} \mathrm{S}$ ) was approximately $52.0 \mathrm{mmol} \mathrm{m} \mathrm{m}^{-2} \mathrm{~d}^{-1},{ }^{1} 15 \%$ higher than previous estimates for this zone. ${ }^{11}$ Similarly, $\mathrm{CH}_{4}$ emission resulting from the exposure of water and mangrove sediments can compensate the blue carbon sedimentation rates in mangrove areas by $20 \% .^{12}$ Recent estimates set for the Amazonian estuary regarding $\mathrm{CO}_{2}$ and $\mathrm{CH}_{4}$ fluxes in the water/atmosphere interface ranged from 174.0 mmol $\mathrm{CO}_{2} \mathrm{~m}^{-2} \mathrm{~d}^{-1}$ to $855.0 \mu \mathrm{mol} \mathrm{CH} \mathrm{Cm}^{-2} \mathrm{~d}^{-1}$, respectively, ${ }_{13}^{13}$ much more higher than those previously found in the tropical region.

According to measurements taken by Call et al. (2019) in the Amazonian estuary, spring tides presented 1.64 and 1.74 times higher concentration of $\mathrm{CO}_{2}$ and $\mathrm{CH}_{4}$, respectively, than the neap tides. They found that $p \mathrm{CO}_{2}$ and $\mathrm{CH}_{4}$ concentrations were 2.0 and 1.5 times, respectively, higher at ebb tides than at flood tides. The rainfall variations in Amazonian mangroves, influenced by the lunar phases and seasonality, are also responsible for changes in nutrient contents and chemical properties $(\mathrm{pH}$, redox potential, and salinity) of surface and interstitial waters, ${ }^{14}$ which factors can influence the gases concentrations, and consequently in their fluxes. Considering the lack of information on the $\mathrm{CO}_{2}$ and $\mathrm{CH}_{4}$ exchange between water and atmosphere in tropical estuaries, this work aims to evaluate the influence of tide, seasonality, and water physical-chemical parameters in the $\mathrm{CO}_{2}$ and $\mathrm{CH}_{4}$ fluxes.

\section{Materials and methods}

\section{Study site}

The study was carried out in Mojuim River estuary (Figure 1), within the Mocapajuba Marine Extractive Reserve (21,029 ha), at São Caetano de Odivelas County, Pará State - Brazil. This estuary belongs to the largest continuous mangrove line on the planet, with $7,591 \mathrm{~km}^{2}$, which $2,177 \mathrm{~km}^{2}$ are concentrated in the Pará State, and represents 
$16 \%$ of the Brazilian mangrove. ${ }^{2}$ Freshwater input in this estuary comes from the basins of Mojuim and Mocupajuba rivers, with a mean bathymetric quota of $4.5 \mathrm{~m}(0.3 \mathrm{a} 14.5 \mathrm{~m})$, reaching a height of $4.9 \mathrm{~m}$ during the flood tide, and $3.2 \mathrm{~m}$ during ebb tide - these values are based on the mean tide level. The estuary has two arms in Mojuim River $\left(\mathrm{R}_{\mathrm{a}}\right.$ and $\left.\mathrm{R}_{\mathrm{b}}\right)$; they are interconnected by a bore $\left(\mathrm{F}_{\mathrm{a}}\right.$ and $\left.\mathrm{F}_{\mathrm{b}}\right)$ that divides Macaca Island into two parts (Figure 1). Mojuim River also has intermittent streams $\left(\mathrm{C}_{\mathrm{a}} ; \mathrm{C}_{\mathrm{b}}\right)$ formed by tide movement (Figure 1).

\section{Climatological data}

The study site has humid tropical climate, of the $A m$ type, ${ }^{15}$ short dry season and mean annual precipitation of $2,850 \mathrm{~mm} \cdot{ }^{16}$ Climatological data (1981-2010) were collected in the Automated Surface Observation Meteorological Station of the National Institute of Meteorology (INMET, 2019), located in Soure County (0043'40.18" S, 48³0'56.86" W)-71.5 km Northwest the study site. Precipitation data, during the measurements (2017-2018), were collected in an automated micrometeorological station located on the edge of the Mojuim River, on the outskirts of São Caetano de Odivelas. Two climatic seasons feature the region, namely: dry and rainy seasons. Precipitation influence on estuary decreases in the dry season (July to December) and leads to slight water stratification. ${ }^{14}$

\section{Gas flux determination}

Gases fluxes were performed in two different experiments. In the first experiment measurements were taken throughout a tide cycle in the dry (November 2017) and rainy seasons (March 2018). Samplings were performed within 1-hour intervals (ebb and flood tide) at the neap tide (Square), both in the river $\left(\mathrm{R}_{\mathrm{b}}\right)$ and in the stream $\left(\mathrm{C}_{\mathrm{b}}\right)$ (Figure 1). Night measurements were not made, because monthly measurements (second experiment) happened during daylight. The second experiment lied on measuring gas flux at the neap tide on a monthly basis, in three different locations: river $\left(\mathrm{R}_{\mathrm{a} ; \mathrm{b}}\right)$, bore $\left(\mathrm{F}_{\mathrm{a} ; \mathrm{b}}\right)$ and stream $\left(\mathrm{C}_{\mathrm{a} ; \mathrm{b}}\right)$ (Fig. 1). Monthly measurements were taken at daylight, along a fixed route: from stream $\left(\mathrm{C}_{\mathrm{a}}\right.$ and $\left.\mathrm{C}_{\mathrm{b}}\right)$, to the river $\left(\mathrm{R}_{\mathrm{a}}\right.$ and $\left.\mathrm{R}_{\mathrm{b}}\right)$ and lastly in the bore $\left(\mathrm{F}_{\mathrm{a}}\right.$ and $\left.\mathrm{F}_{\mathrm{b}}\right)$, for one year (2017-2018). In the second experiment, measurements started in the morning and ended in the afternoon, so the first experiment can show the size of the error when comparing the places at different tides.

Flux determination was conducted in a dynamic floating chamber $\left(804.0 \mathrm{~cm}^{2}\right.$ and $\left.9.650 \mathrm{~cm}^{3}\right)$, the same as described by Jacotot ${ }^{17}$ which was connected to a gas analyzer coupled to the automated system Ultra-portable Greenhouse Gas Analyzer (model 915-0011-1000), Los Gatos Research. ${ }^{18}$ The equipment was previously calibrated for $\mathrm{CO}_{2}(0.395$ and $1.510 \mathrm{ppm})$ and $\mathrm{CH}_{4}(0.94$ and $3.15 \mathrm{ppm})$ gas standards. Each measurement took 4-min period-of-time, with the automated and simultaneous measurement of the gases concentration (ppm), at a frequency of $2 \mathrm{~Hz}$. Collections were conducted with the aid of an aluminum boat, which was moored in position equidistant to the riversides.

Air-water exchanges in the field are difficult to measure, and difficult to interpret because the gas exchange coefficient depends on many environmental factors, the main ones being wind speed, air and sea turbulence, presence of organic matter or hydrocarbon at the airsea, bubble formation. ${ }^{19,20}$ It is known that floating chambers can induce an overestimation of fluxes results in intense windy conditions or with strong river flowing, which induces turbulence. ${ }^{21-23}$ However, in low turbulence environments, such as stream and bore, where the wind is almost zero and the water flow is slow, the floating chamber technique can be a powerful method. ${ }^{24-26}$ Also, to reduce the error, we choose the moments at the neap tide when the river has less turbulence. ${ }^{17,27}$ Thus, we are sure of the credibility of our measurements. In addition, floating chambers have the ability to capture boiling events that can account for a large proportion of the gas transferred to the atmosphere, particularly $\mathrm{CH}_{4}{ }^{28}$ The $\mathrm{CO}_{2}$ and $\mathrm{CH}_{4}$ flux through the water surface was calculated according to the difference in concentration within the chamber, over three minutes. ${ }^{17,19}$ In the present study, only regressions that showed an inclination line whit $\mathrm{R}^{2} \geq 0.3$ were considered flux, otherwise, the fluxes were considered zero (Sundqvist et al., 2014).

\section{Environmental parameters}

Manual Thermo-Higro-Anemometer device (model AK821) was used (at height $1.0 \mathrm{~m}$ from the top of the water column) to measure air temperature $\left(\mathrm{Ta} ;{ }^{\circ} \mathrm{C}\right)$, relative air humidity $(\mathrm{RH} ; \%)$ and wind speed (Ws; $\mathrm{m} \mathrm{s}^{-1}$ ). Horiba multiparametric probe (model - U50G) was applied to register water temperature $\left(\mathrm{Tw} ;{ }^{\circ} \mathrm{C}\right), \mathrm{pH}$, redox potential (ORP, $\mathrm{mV}$ ), dissolved oxygen (DO, $\mathrm{mg} \mathrm{L}^{-1}$ ), electric conductivity (EC, $\mu \mathrm{S} \mathrm{cm}^{-1}$ ), turbidity (Tur; NTU), salinity (S; PPT), and total dissolved solids (TDS, $\mathrm{g} \mathrm{L}^{-1}$ ). All environmental variables were carried out simultaneously with gas flux measurements.

\section{Statistical Analysis}

Normal distribution data found based on the Shapiro-Wilks adjustment method were compared through analysis of variance (ANOVA) and tested through Fisher Method (LSD), at significance difference higher than $95 \%$. Non-normal data distributions were subjected to Kruskal-Wallis test, at significance difference higher than $95 \%$, or, yet, to normalization carried out through logarithmic transformation. Pearson's correlation coefficient was used to assess correlations between environmental features and $\mathrm{CO}_{2}$ and $\mathrm{CH}_{4}$ flux. The analyses were performed in InfoStat ${ }^{\circledR}$ software (free version).

\section{Results}

\section{Precipitation and tide seasonality}

The study site was featured by dry season (less rainy) from July to December and rainy season from January to June, which are in agreement with local climatology (Figure 2). Total precipitation in the dry season was $1,016.0 \mathrm{~mm}$, and 2,155.0 $\mathrm{mm}$ in the rainy season. When compared to climatological data, the rainy season registered $553.2 \mathrm{~mm}$ less, and the dry season presented $589.1 \mathrm{~mm}$ more than the Climatological Normal. The lowest tide was observed in July 2017, whereas the highest tide was observed in May 2018 (Figure 2). Such different water volumes resulted in current speed in the rainy season, which reached $1.6 \mathrm{~m} \mathrm{~s}^{-1}$ at the high tide and $1.9 \mathrm{~m} \mathrm{~s}^{-1}$ in the low tide, whereas currents in the dry season reached $1.2 \mathrm{~m} \mathrm{~s}^{-1}$ at the ebb tide and $1.6 \mathrm{~m} \mathrm{~s}^{-1}$ at the high tide. ${ }^{14}$

\section{Gas flux based on tide moves and environmental parameters}

These results are only one day of sampling (in the rainy and dry season), as explained above, and were collected to calculate the contribution of tide height in the gases fluxes and in the water physicochemical parameters. The assessed sites behaved as $\mathrm{CO}_{2}$ and $\mathrm{CH}_{4}$ source to the atmosphere (Figure 3). Mean $\mathrm{CO}_{2}$ flux in the dry season at the ebb tide did not differ $(\mathrm{LSD}=151.3, \mathrm{p}=0.40)$ between river $\left(114.00 \pm 48.01 \mathrm{mmol} \mathrm{CO}_{2} \mathrm{~m}^{-2} \mathrm{~d}^{-1}\right)$ and stream $(175.39 \pm 48.01$ mmol $\left.\mathrm{CO}_{2} \mathrm{~m}^{-2} \mathrm{~d}^{-1}\right)$. Similarly, $\mathrm{CO}_{2}$ fluxes at the flood tide, in the dry season, were $119.22 \pm 20.61 \mathrm{mmol} \mathrm{CO}_{2} \mathrm{~m}^{-2} \mathrm{~d}^{-1}$ and $42.47 \pm 38.55 \mathrm{mmol}$ 
$\mathrm{CO}_{2} \mathrm{~m}^{-2} \mathrm{~d}^{-1}$, in the river and in the stream, respectively - there was no statistically significant difference between the assessed sites (LSD: 103.4; $\mathrm{p}=0.12$ ). $\mathrm{CH}_{4}$ fluxes in this same season, at the ebb tide, did not differ (LSD: $2.5 ; \mathrm{p}=0.83)$ between river $\left(1.76 \pm 0.29 \mathrm{mmol} \mathrm{CH}_{4} \mathrm{~m}^{-2} \mathrm{~d}^{-1}\right)$ and stream $\left(2.00 \pm 0.78 \mathrm{mmol} \mathrm{CH}_{4} \mathrm{~m}^{-2} \mathrm{~d}^{-1}\right)$ - the same outcome was observed in the flood tide, when mean $\mathrm{CH}_{4}$ fluxes recorded $2.35 \pm$ $0.60 \mathrm{mmol} \mathrm{CH}_{4} \mathrm{~m}^{-2} \mathrm{~d}^{-1}$ and $2.00 \pm 1.13 \mathrm{mmol} \mathrm{CH}_{4} \mathrm{~m}^{-2} \mathrm{~d}^{-1}$, in the river and stream, respectively (LSD: $3.0 ; p=0.79$ ). Based on the results, the dry season did not present gas flux variation due to water column height; in other words, tide moves did not influence $\mathrm{CO}_{2}$ and $\mathrm{Ch}_{4}$ flux Figure 3. The rainy season did not show significant difference (LSD: 389.7; $\mathrm{p}=0.37$ ) between $\mathrm{CO}_{2}$ flux in the river, between the ebb tide $\left(213.4 \pm 129.9 \mathrm{mmol} \mathrm{CO}_{2} \mathrm{~m}^{-2} \mathrm{~d}^{-1}\right)$ and the flood tides $(377.7 \pm 120.3$ mmol $\mathrm{CO}_{2} \mathrm{~m}^{-2} \mathrm{~d}^{-1}$ ) (Figure 4). However, $\mathrm{CH}_{4}$ flux in the river was significantly higher (LSD: $2.3 ; \mathrm{p}=0.02)$ at the ebb tide $(4.3 \pm 1.0 \mathrm{mmol}$ $\left.\mathrm{CH}_{4} \mathrm{~m}^{-2} \mathrm{~d}^{-1}\right)$ than at the flood tide $\left(1.4 \pm 0.7 \mathrm{mmol} \mathrm{CH}_{4} \mathrm{~m}^{-2} \mathrm{~d}^{-1}\right)$ Figure 4.

\section{Gas flux seasonality}

The results presented here refer to the monthly sampling the $\mathrm{CO}_{2}$ and $\mathrm{CH}_{4}$ fluxes at the water/atmosphere interface throughout the hydrological year, in which the water was source for two studied gases (Figure 5). The river recorded higher mean annual equivalent $\mathrm{CO}_{2}\left(\mathrm{CO}_{2}\right.$-e) flux of $542.5 \mathrm{mmol} \mathrm{CO}_{2}-\mathrm{e} \mathrm{m}^{-2} \mathrm{~d}^{-1}$, which was followed by the stream $\left(531.3 \mathrm{mmol} \mathrm{CO}_{2}\right.$-e $\left.\mathrm{m}^{-2} \mathrm{~d}^{-1}\right)$ and the bore $(413.0 \mathrm{mmol}$ $\mathrm{CO}_{2}-\mathrm{e} \mathrm{m}^{-2} \mathrm{~d}^{-1}$ ) (Table 1). However, these results did not significantly differ $(\mathrm{LSD}=231.8 ; \mathrm{p}=0.80)$ between locations (Table 1$). \mathrm{CO}_{2}$ flux comparison between the assessed locations, within each season, showed no difference in the dry season $(\mathrm{LSD}=201.2 ; \mathrm{p}=0.61)$, or in the rainy season $(\mathrm{LSD}=335.5 ; \mathrm{p}=0.82)$, and the same happened with $\mathrm{CH}_{4}(\mathrm{p}=0.73$ and 0.67 , respectively) Figure 5, Table 1 . In seasonal terms, $\mathrm{CO}_{2}$ and $\mathrm{CH}_{4}$ flux in the assessed locations was higher in the rainy season than in the dry season - such difference was significant for $\mathrm{CO}_{2}$ and $\mathrm{CO}_{2}$-e (Table 1). With respect to $\mathrm{CH}_{4}$ flux, although it was higher in the rainy season, there was no significant seasonal variation in the river $(\mathrm{LSD}=1.66 ; \mathrm{p}=0.573)$, bore $(\mathrm{LSD}=1.52 ; \mathrm{p}=0.965)$ and stream $(\mathrm{LSD}=4.43 ; \mathrm{p}=0.470)$.

\section{Monthly gas flux}

Carbon dioxide flux in the river was higher in January $\left(1,031.1 \pm 254.8 \mathrm{mmol} \mathrm{CO}_{2} \mathrm{~m}^{-2} \mathrm{~d}^{-1}\right)$ and lower in October $(782.8 \pm 437.4$ mmol $\mathrm{CO}_{2} \mathrm{~m}^{-2} \mathrm{~d}^{-1}$ ) (Figure 6). This flux in bores was higher in April $\left(1,111.3 \pm 336.2 \mathrm{mmol} \mathrm{CO}_{2} \mathrm{~m}^{-2} \mathrm{~d}^{-1}\right)$ and lower in May $(695.5 \pm 170.2$ mmol $\left.\mathrm{CO}_{2} \mathrm{~m}^{-2} \mathrm{~d}^{-1}\right)$. Gas flux in the stream was higher in January $\left(1973.9 \pm 163.8 \mathrm{mmol} \mathrm{CO}_{2} \mathrm{~m}^{-2} \mathrm{~d}^{-1}\right)$ and lower in February $(1007.9 \pm$ $\left.291.0 \mathrm{mmol} \mathrm{CO}_{2} \mathrm{~m}^{-2} \mathrm{~d}^{-1}\right)$. When $\mathrm{CO}_{2}$ flux between river and stream per month was compared, it was possible observing significant differences in January $\left(1,973.9 \pm 163.8 \mathrm{mmol} \mathrm{CO}_{2} \mathrm{~m}^{-2} \mathrm{~d}^{-1}\right)$ August (LSD: 144.79, $\mathrm{p}=0.00$ ) and September - in other words, at the beginning of the rainy and dry seasons Figure 6 or Figure 5.

Table I Mean $\mathrm{CO}_{2}, \mathrm{CH}_{4}$ flux, and mean annual $\mathrm{CO}_{2}$-e* from the river, bore and stream in the dry and rainy seasons in Mojuim River estuary. Lowercase letters compare locations in each period, capital letters compare climatic periods. When letters are different, significance is greater than $95 \%$

\begin{tabular}{|c|c|c|c|c|c|c|c|c|c|c|c|c|}
\hline \multirow[t]{2}{*}{ Season } & \multicolumn{4}{|c|}{$\mathrm{CO}_{2}\left(\mathrm{mmol} \mathrm{m} \mathrm{m}^{-2} \mathrm{~d}^{-1}\right)$} & \multicolumn{4}{|c|}{$\mathrm{CH}_{4}\left(\mathrm{mmol} \mathrm{m}^{-2} \mathrm{~d}^{-1}\right)$} & \multicolumn{4}{|c|}{$\mathrm{CO}_{2}-\mathrm{e}\left(\mathrm{mmol} \mathrm{m}^{-2} \mathrm{~d}^{-1}\right)$} \\
\hline & River & Bore & Stream & Mean & River & Bore & Stream & Mean & River & Bore & Stream & Mean \\
\hline Dry & $272.1 \pm 87.9^{\mathrm{aB}}$ & $170.4 \pm 54 .\left.\right|^{\mathrm{aB}}$ & $239.8 \pm 60.8^{\mathrm{aB}}$ & $230.8 \pm 40.7^{\mathrm{B}}$ & $2.1 \pm 0.5^{\mathrm{aA}}$ & $2.7 \pm 0.5^{\mathrm{aA}}$ & $2.5 \pm 0.6^{\mathrm{aA}}$ & $2.4 \pm 0.3^{\mathrm{A}}$ & $320.7^{\mathrm{aB}}$ & $233.3^{\mathrm{aB}}$ & $297.6^{\mathrm{aB}}$ & $286.8^{\mathrm{B}}$ \\
\hline Rainy & $705.0 \pm 88.9^{\mathrm{aA}}$ & $601.0 \pm 115 . I^{\mathrm{aA}}$ & $670.3 \pm 145.9^{\mathrm{aA}}$ & $658.8 \pm 67.9^{A}$ & $2.6 \pm 0.6^{\mathrm{aA}}$ & $2.8 \pm 0.6^{\mathrm{aA}}$ & $4.1 \pm 2 . I^{\mathrm{aA}}$ & $3.2 \pm 0.8^{\mathrm{A}}$ & $764.3 \mathrm{a}^{\mathrm{A}}$ & $562.9^{\mathrm{aA}}$ & $764.9^{\mathrm{aA}}$ & $731.3^{\mathrm{A}}$ \\
\hline Mean & $488.5 \pm 69.4^{a}$ & $405.3 \pm 74.3^{a}$ & $455.0 \pm 84.2^{\mathrm{a}}$ & $450.9 \pm 43.9$ & $2.4 \pm 0.4^{\mathrm{a}}$ & $2.75 \pm 0.4^{\mathrm{a}}$ & $3.3 \pm 1.1^{\mathrm{a}}$ & $2.8 \pm 0.4$ & $542.5^{\mathrm{a}}$ & $413.0^{\mathrm{a}}$ & $531.3^{a}$ & 515.4 \\
\hline
\end{tabular}

*Global warming potential from 23 for $\mathrm{CH}_{4}$ was used to convert $\mathrm{CH} 4$ emission into $\mathrm{CO}_{2}$-e in order to compare its impacts on the greenhouse effect.(IPCC, $2013)$.

Table 2 Monthly and seasonal values of $\mathrm{CO}_{2}\left(\mathrm{mmol} \mathrm{m}^{-2} \mathrm{~d}^{-1}\right), \mathrm{CH}_{4}\left(\mathrm{mmol} \mathrm{m}^{-2} \mathrm{~d}^{-1}\right)$, water temperature $\left(\right.$ Tw; $\left.{ }^{\circ} \mathrm{C}\right)$, $\mathrm{pH}$, Dissolved Oxygen $\left(\mathrm{DO}\right.$; mg $\left.\mathrm{L}^{-1}\right)$, Turbidity $($ Tur;

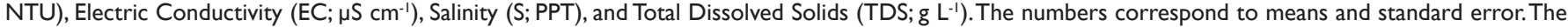
symbols * and \# represents significant correlation $(\mathrm{p}<0.05)$ between $\mathrm{CO}_{2}$ and $\mathrm{CH}_{4}$ and the variables assessed through Pearson's analysis

\begin{tabular}{|c|c|c|c|c|c|c|c|c|c|}
\hline Month & $\mathrm{CO}_{2}$ & $\mathrm{CH}_{4}$ & Tw & $\mathrm{pH}$ & DO & EC & Tur & $\mathbf{S}$ & TDS \\
\hline Jul-I7 & $163.2(106.3)$ & $4.8(0.9)$ & $28.5(0.1)$ & $7.2(0.2)^{\#}$ & $4.3(0.5)$ & $28.9(0.5)$ & $25.4(1.8)$ & I.8(0.0) & $17.9(0.3)$ \\
\hline August & $183.9(38.6)$ & $2.2(0.5)$ & $29.7(0.1)^{*}$ & $7.3(0.1)^{\#}$ & $4.4(0.8)$ & $37.0(1.5)^{\#}$ & 19.4(I.3) & $2.4(0.1) \#$ & $22.6(0.9)^{\#}$ \\
\hline September & $255.4(57.5)$ & $3.2(0.8)$ & $29.8(0.2)$ & $7.7(0.1)$ & $6.1(0.6)$ & $42.1(1.0)$ & $47.9(17.4)$ & $2.7(0.1)$ & $25.7(0.6)$ \\
\hline October & $468.5(169.8)$ & I.0(0.8) & $30.4(0.1)$ & $7.3(0.5)^{\#}$ & $3.0(0.5)$ & $46.8(0.7)$ & $8.5(0.5)$ & $3 . I(0.1)$ & $28.6(0.4)$ \\
\hline November & $108.9(16.8)$ & $2.0(0.9)$ & $29.0(0.2)$ & $7.8(0.2)$ & $2.4(1.0)$ & $23.2(6.0)^{\#}$ & $26.0(4.3)$ & $1.9(0.1)$ & $14.3(3.5)^{\#}$ \\
\hline December & I64.3(70.6) & I.3(0.4) & $30.5(0.1)$ & $7.9(0.5)$ & $4.4(0.9)$ & $55.8(5.0)$ & $6.9(0.6)$ & $3.3(0.0)$ & $30.7(0.2)$ \\
\hline Dry Season & $230.8(40.7)$ & $2.4(0.3)$ & $29.7(0.2)^{\#}$ & $7.5(0.1)$ & $4.2(0.3)$ & $39.9(2.1)$ & $22 . I(3.8)$ & $2.6(0.1)$ & $23.8(1.0)$ \\
\hline Jan-18 & I,248.9(I88.I) & I.3(0.2) & $29.6(0.1)^{* ; \#}$ & $6.6(0.5)^{*}$ & $4 . I(0.4)$ & $34.2(0.5)^{* ; \#}$ & $8 . I^{*}(I .3)$ & $2.3(0.1)$ & $20.9(0.3)^{* ; \#}$ \\
\hline February & $567.8(154.8)$ & $7.6(4.1)$ & $29.2(0.2)^{\#}$ & $8.6(0.9)^{*}$ & $3.2(0.4)$ & $16.7(1.5)^{\#}$ & $36.8(12.0)$ & $1.0(0.1)^{\#}$ & $10.4(0.9)^{\#}$ \\
\hline March & $251.4(87.1)$ & $1.6(0.4)$ & $29.6(0.1)$ & $8 . I(0.3)$ & $12.7(1.3)$ & $12.0(0.8)$ & $29.6(18.9)$ & $0.7(0.1)$ & $7.5(0.5)$ \\
\hline April & $738.6(164.8)$ & I.7(0.7) & $29.3(0.2)$ & $7.2(0.4)$ & $9.2(1.8)$ & II.2(0.6) & $15.6(2.7)$ & $0.6(0.0)$ & $7 . I(0.3)$ \\
\hline May & $772.6(127.5)$ & $1.9(0.4)$ & $28.9(0.0)$ & $7.7(0.3)$ & $7.2(1.2)$ & $13.2(0.7)$ & $16.2(2.8)$ & $0.8(0.1)$ & $8.2(0.5)$ \\
\hline June & $373.1(106.8)$ & $4.9(1.3)$ & $29.0(0.3)$ & $7.5(0.1)$ & $3.6(0.6)$ & $36.6(11.3)$ & I5.5(2.0) & $1.6(0.1)$ & $16.7(1.1)$ \\
\hline Rainy Season & $658.8(67.9)$ & $3.2(0.8)$ & $29.3(0.1)$ & $7.6(0.2)^{* ; \#}$ & $6.8(0.7)$ & $20.6(2.5)$ & $20.3(3.9)^{\#}$ & $1.2(0.1)^{*}$ & I I.8(0.9) \\
\hline
\end{tabular}


Table 3 Maximum (Max), minimum (Min) and mean \pm stander error (Mean) of values recorded for environmental variables: Air temperature (Tar, $\left.{ }^{\circ} \mathrm{C}\right)$, Water temperature $\left(\mathrm{Tw}^{\circ} \mathrm{C}\right)$, Redox potential (ORP, mV), Dissolved oxygen (DO, mg L $\left.\mathrm{L}^{-1}\right)$, Electrical conductivity (EC, $\left.\mu \mathrm{S} \mathrm{cm}{ }^{-1}\right)$, Turbidity (Tur, NTU), and Salinity (S, PPT), in the dry and rainy season, at the ebb tides and floods, in Mojuim River estuary

\begin{tabular}{|c|c|c|c|c|c|}
\hline Variable & Range & Dry Season & & Rainy Season & \\
\hline & & Ebb tide & Flood tide & Ebb tide & Flood tide \\
\hline \multirow[t]{3}{*}{ Tar } & Max & 32.1 & 33 & 32.1 & 33.1 \\
\hline & Min & 30.5 & 31 & 30.6 & 31.7 \\
\hline & Mean & $31.33 \pm 0.27$ & $32.01 \pm 0.25$ & $31.48 \pm 0.27$ & $32.29 \pm 0.19$ \\
\hline \multirow[t]{3}{*}{ Tw } & Max & 30.05 & 30.16 & 29.42 & 29.59 \\
\hline & Min & 29.3 & 29.82 & 28.37 & 29.28 \\
\hline & Mean & $29.58 \pm 0.12$ & $29.98 \pm 0.05$ & $29.19 \pm 0.16$ & $29.39 \pm 0.05$ \\
\hline \multirow[t]{3}{*}{$\mathrm{pH}$} & Max & 8.06 & 8.07 & 9.38 & 9.49 \\
\hline & Min & 7.94 & 7.96 & 8.09 & 7.73 \\
\hline & Mean & $8.00 \pm 0.02$ & $8.00 \pm 0.01$ & $8.54 \pm 0.20$ & $8.26 \pm 0.28$ \\
\hline \multirow[t]{3}{*}{ ORP } & Max & 158 & 175 & 260 & 254 \\
\hline & Min & 140 & 152 & 184 & 137 \\
\hline & Mean & $149.00 \pm 2.66$ & $165.57 \pm 3,15$ & $210.33 \pm 10.68$ & $199.00 \pm 19,67$ \\
\hline \multirow[t]{3}{*}{ DO } & Max & 1.53 & 2.55 & 9.38 & 9.5 \\
\hline & Min & 0.65 & 1.32 & 4.97 & 5.72 \\
\hline & Mean & $1.03 \pm 0.14$ & $2.00 \pm 0.16$ & $7.89 \pm 0.62$ & $7.65 \pm 0.47$ \\
\hline \multirow[t]{3}{*}{ EC } & Max & 46.9 & 47.7 & 15.6 & 12.5 \\
\hline & Min & 29.2 & 38.8 & 12.7 & 11.5 \\
\hline & Mean & $40.73 \pm 2.61$ & $44.73 \pm 1.24$ & $13.80 \pm 0.49$ & $12.00 \pm 0.13$ \\
\hline \multirow[t]{3}{*}{ Tur } & Max & 88.9 & 88.4 & 266 & 195.9 \\
\hline & Min & 82.5 & 29.2 & 123 & 127.3 \\
\hline & Mean & $85.67 \pm 1.15$ & $76.33 \pm 7.91$ & $174.23 \pm 19.75$ & $|75.07 \pm 9.2|$ \\
\hline \multirow[t]{3}{*}{ S } & Max & 3.04 & 3.11 & 0.91 & 0.76 \\
\hline & Min & 1.38 & 2.45 & 0.73 & 0.65 \\
\hline & Mean & $2.36 \pm 0.27$ & $2.90 \pm 0.09$ & $0.80 \pm 0.03$ & $0.69 \pm 0.01$ \\
\hline
\end{tabular}

Mean $\mathrm{CH}_{4}$ flux in the river and bore was significantly higher in June (river $=7.1 \pm 2.9 \mathrm{mmol} \mathrm{CH}_{4} \mathrm{~m}^{-2} \mathrm{~d}^{-1}$; bore $=5.1 \pm 2.6 \mathrm{mmol} \mathrm{CH}_{4}$ $\left.\mathrm{m}^{-2} \mathrm{~d}^{-1}\right)$ and lower in September (river $=5.6 \pm 1.0 \mathrm{mmol} \mathrm{CH}_{4} \mathrm{~m}^{-2} \mathrm{~d}^{-1}$; bore $=3.8 \pm 0.7 \mathrm{mmol} \mathrm{CH}_{4} \mathrm{~m}^{-2} \mathrm{~d}^{-1}$ ). It was possible observing high values in the stream in February $\left(19.4 \pm 10.4 \mathrm{mmol} \mathrm{CH}_{4} \mathrm{~m}^{-2} \mathrm{~d}^{-1}\right)$ and July (Figure 6). The comparison between river and stream flux showed significant difference in $\mathrm{CH}_{4}$ flux in January (LSD: 0.63, $\mathrm{p}=$ 0.010), May (LSD: 0.86, $\mathrm{p}<0.000$ ) and September (LSD: 2.38 , $\mathrm{p}<$ 0.00 ). Gas flux in the water/atmosphere interface was always higher in the rainy season than in the dry season, except for $\mathrm{CH}_{4}$ flux in the bore (Table 1). Annual $\mathrm{CO}_{2}$ emissions from the river were $6.9 \%$ and $21.1 \%$ higher than flux in the stream and bore, respectively. Annual mean $\mathrm{CH}_{4}$ flux was higher in the stream, it was $17.0 \%$ and $29.2 \%$ higher than that recorded for the bore and river, respectively. Based on the assessed Amazonian estuary, Mojuim River estuary releases $7.241 \mathrm{~kg}$ $\mathrm{CO}_{2} \mathrm{~m}^{-2} \mathrm{yr}^{-1}$ and $0.016 \mathrm{~kg} \mathrm{CH}_{4} \mathrm{~m}^{-2} \mathrm{yr}^{-1}$ into the atmosphere.

Despite the low monthly Tw variation (Table 2 ), it was significantly higher $(\mathrm{LSD}=0.43 ; \mathrm{p}<0.000)$ in December $\left(30.5^{\circ} \mathrm{C}\right)$ and October $\left(30.4{ }^{\circ} \mathrm{C}\right)$, and lower in July $\left(28.5^{\circ} \mathrm{C}\right)$. There was positive correlation to $\mathrm{CO}_{2}$ in August and January, and to $\mathrm{CH}_{4}$ in January and February (Table 2). The $\mathrm{pH}$ was only significantly higher in February (LSD = $1.15 ; \mathrm{p}=0.010)$ than the lowest $\mathrm{pH}$ recorded in January, which was negatively correlated to $\mathrm{CO}_{2}$ in January (Pearson $=-0.83 ; \mathrm{p}=0.040$ ) and February (Pearson $=-0.84 ; \mathrm{p}=0.030$ ). Correlation between $\mathrm{CH}_{4}$ and $\mathrm{pH}$ was positive in July (Pearson $=0.87 ; \mathrm{p}=0.030)$ and October $($ Pearson $=0.93 ; \mathrm{p}<0.000)$, and negative in August $($ Pearson $=-0.84$; $\mathrm{p}=0.040)($ Table 2). Alkaline water $\mathrm{pH}$ (Table 2) indicated the strong influence of tide cycle on the study site.

DO was significantly $(\mathrm{LSD}=2.66 ; \mathrm{p}<0.000)$ higher in March
(12.7 $\left.\mathrm{mg} \mathrm{L}^{-1}\right)$ and lower in February $\left(3.2 \mathrm{mg} \mathrm{L}^{-1}\right)$, October $\left(3.0 \mathrm{mg} \mathrm{L}^{-1}\right)$ and November $\left(2.4 \mathrm{mg} \mathrm{L}^{-1}\right)$. It did not present monthly correlation to $\mathrm{CO}_{2}$ and $\mathrm{CH}_{4}$ (Table 2). ORP was significantly higher ( $\mathrm{LSD}=37.78$; $\mathrm{p}<0.000)$ in April $(256.7 \mathrm{mV})$, May $(251.0 \mathrm{mV})$, August $(250.2$ $\mathrm{mV}$ ) and January $(243.8 \mathrm{mV})$, and lower in February $(243.8 \mathrm{mV})$. It presented significant correlation to $\mathrm{CH}_{4}$ only in December (Pearson $=0.83 ; \mathrm{p}=0.040)$. Tur was significantly higher $(\mathrm{LSD}=24.53 ; \mathrm{p}=$ 0.030 ) in November (47.9 NTU) and lower in October (8.5 NTU), January (8.1 NTU) and December (6.9 NTU). It only presented positive correlation to $\mathrm{CO}_{2}$ in January (Pearson $=0.92 ; \mathrm{p}=0.009$ ).

EC was significantly $(\mathrm{LSD}=11.22 ; \mathrm{p}<0.000)$ higher in December $\left(55.8 \mu \mathrm{S} \mathrm{cm}^{-1}\right)$ and lower in February $\left(16.7 \mu \mathrm{S} \mathrm{cm}^{-1}\right)$, May $(13.2 \mu \mathrm{S} \mathrm{cm}$ $\left.{ }^{1}\right)$, March $\left(12.0 \mu \mathrm{S} \mathrm{cm}^{-1}\right)$ and April $\left(11.2 \mu \mathrm{S} \mathrm{cm}^{-1}\right)$. There was negative EC correlation to $\mathrm{CO}_{2}$ in January (Pearson $=-0.83 ; \mathrm{p}=0.04$ ). $\mathrm{CH}_{4}$ flux had positive correlation to EC in January (Pearson $=0.94 ; p=0.010$ ), February $($ Pearson $=0.87 ; \mathrm{p}=0.02)$ and November $($ Pearson $=0.99$; $\mathrm{p}=0.01)$, and negative correlation to it in August (Pearson $=-0.90 ; \mathrm{p}$ $=0.020)$ (Table 2$)$. S was significantly $(\mathrm{LSD}=0.24 ; \mathrm{p}<0.000)$ higher in December (3.3 PPT) and lower in March (0.7 PPT) and April (0.6 PPT). It was negatively correlated to $\mathrm{CH}_{4}$ in August (Pearson $=-0.90$; $\mathrm{p}=0.019$ ) and positively correlated to it in February (Pearson $=0.87$; $\mathrm{p}=0.016)$. The amount of TDS was significantly (LSD $=2.50 ; \mathrm{p}<$ $0.000)$ higher in December $\left(30.7 \mathrm{~g} \mathrm{~L}^{-1}\right)$ and October $\left(28.6 \mathrm{~g} \mathrm{~L}^{-1}\right)$, and lower in March $\left(7.5 \mathrm{~g} \mathrm{~L}^{-1}\right)$ and April $\left(7.1 \mathrm{~g} \mathrm{~L}^{-1}\right)$. There was negative correlation between TDS and $\mathrm{CO}_{2}$ in January (Pearson $=-0.85 ; \mathrm{p}=$ 0.025 ), and the correlation to $\mathrm{CH}_{4}$ was negative in August (Pearson $=-0.90 ; \mathrm{p}=0.023)$ and positive in November $($ Pearson $=0.96 ; \mathrm{p}=$ $0.042)$, January $($ Pearson $=0.94 ; \mathrm{p}=0.012)$ and February $($ Pearson $=$ $0.87 ; \mathrm{p}=0.034)$. 


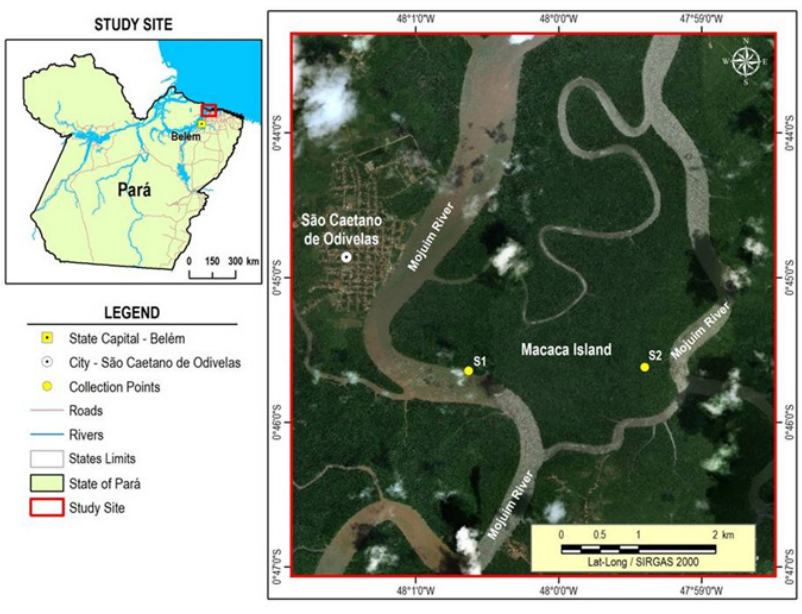

Figure I São Caetano de Odivelas County location, with emphasis on Macaca Island, and Mojuim River estuary. The respective sampling points are $\mathrm{Ca} ; \mathrm{b}$ in the stream, Fa; $b$ in the bore and $\mathrm{Ra} ; \mathrm{b}$ in the river.

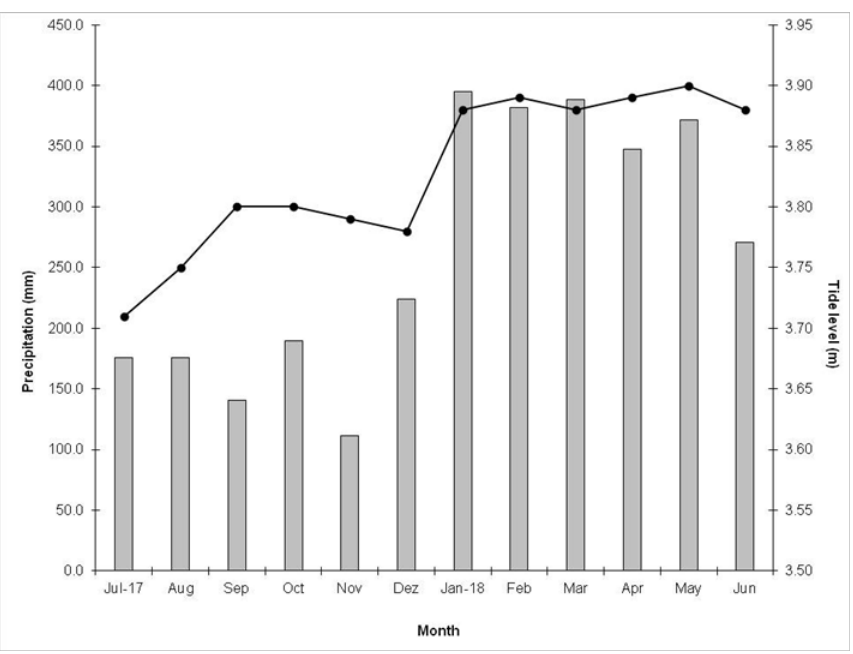

Figure 2 Climatological Normal (|98|-20|0) in Soure County, and precipitation $(\mathrm{mm})$ and maximum tide height $(\mathrm{m})$, in 2017 and 2018 , in São Caetano de Odivelas County.

\section{Discussion}

Some studies have shown reverse association between $\mathrm{CO}_{2}$ and $\mathrm{CH}_{4}$ emission magnitude due to water column thickness on mangrove soil. ${ }^{31,32}$ The water column has only influenced $\mathrm{CH}_{4}$ flux in the rainy season, in the present study - this finding corroborates results in other studies. ${ }^{33}$ However, different from the above mentioned studies, $\mathrm{CO}_{2}$ flux was not influenced by tide moves, in the current research. Gas flux into the atmosphere can occur due to upward diffusion ${ }^{34}$ and gas microbubbles, mainly when it comes to $\mathrm{CH}_{4}$, given its lower solubility. ${ }^{35,36}$ The influence of gas bubbles seems to be more important on $\mathrm{CH} 4$ flux when measured in the river, mainly in the ebb, as fluxes variations were greater than when the tide was rising. ${ }^{36}$ Based on our study, the influence of the microbubbles was only on the $\mathrm{CO}_{2}$ flux, increasing the concentration of more than a thousand times inside the chamber. In the few times that this happened, a lot of noise was observed in the flux, leaving the slope line in the accumulation curve $\mathrm{R}^{2}<0.3$, and therefore the fluxes were considered zero. ${ }^{37}$ A study carried out in Bragantina's region, Amazonian estuary, has shown variation in concentration of $\mathrm{CO}_{2}$ and $\mathrm{CH}_{4}$ dissolved in the water surface through a tidal cycle in a mangrove stream, in the dry season Call et al., 2019 However, based on our results, a high $\mathrm{CO}_{2}$ and $\mathrm{CH}_{4}$ concentration in the water column, at the low tides, may not result in a greatest gas flux (Figure 4).

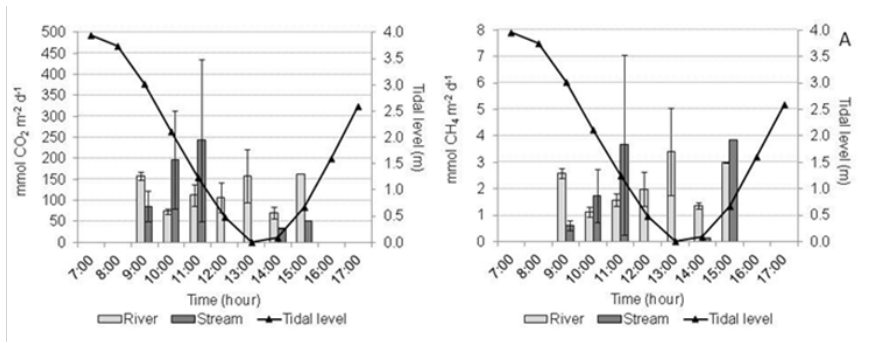

Figure 3 Mean $\mathrm{CO}_{2}\left(\mathrm{mmol} \mathrm{m}^{-2} \mathrm{~d}^{-1}\right)$ and $\mathrm{CH}_{4}\left(\mathrm{mmol} \mathrm{m}^{-2} \mathrm{~d}^{-1}\right)$ flux on water surface in comparison to tide level variation, at different times of the day. (A) $\mathrm{CO}_{2}$ and $\mathrm{CH}_{4}$ flux in the river and stream in the dry season.
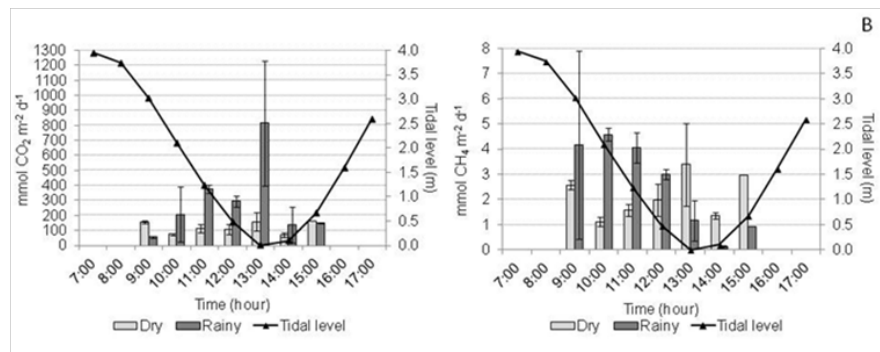

Figure 4 (B) $\mathrm{CO}_{2}$ and $\mathrm{CH}_{4}$ flux during the rainy and dry season in the river, only. The bars indicate the mean standard error.

Some previous research that have assessed the link between tidal movement and $\mathrm{CO}_{2}$ and $\mathrm{CH}_{4}$ flux have shown flux of $116 \pm 103 \mathrm{mmol}$ $\mathrm{CO}_{2} \mathrm{~m}^{-2} \mathrm{~d}^{-1}($ mean $\pm \mathrm{SD})$ and $800 \pm 419 \mu \mathrm{mol} \mathrm{CH}_{4} \mathrm{~m}^{-2} \mathrm{~d}^{-1}$ at the high tide, and of $214 \pm 130 \mathrm{mmol} \mathrm{CO}_{2} \mathrm{~m}^{-2} \mathrm{~d}^{-1}$ and $895 \pm 391 \mu \mathrm{mol} \mathrm{CH}_{4} \mathrm{~m}^{-2}$ $\mathrm{d}^{-1}$ at the ebb tide. ${ }^{38}$ Similarly, results concerning the river have shown that $\mathrm{CO}_{2}$ flux at the flood tide was higher than at the ebb tide either in the dry or in the rainy seasons. However, $\mathrm{CH}_{4}$ flux has behaved in the reverse way, when the two climatic periods were compared to each other. Accordingly, as shown by Costa et al. (2018) about water speed move, $\mathrm{CO}_{2}$ flux is higher when water is less rough - the opposite has happened with $\mathrm{CH}_{4}$.

Mean flux was $1,813 \pm 623 \mu \mathrm{mol} \mathrm{CH}_{4} \mathrm{~m}^{-2} \mathrm{~d}^{-1}$ at the ebb tide and $2,579 \pm 1,077 \mu \mathrm{mol} \mathrm{CH} \mathrm{m}^{-2} \mathrm{~d}^{-1}$ at the flood tide, in the rainy season, $3,956 \pm 673 \mu \mathrm{mol} \mathrm{CH}_{4} \mathrm{~m}^{-2} \mathrm{~d}^{-1}$ (ebb tide) and $734 \pm 559 \mu \mathrm{mol} \mathrm{CH}_{4} \mathrm{~m}^{-2}$ $\mathrm{d}^{-1}$ (flood tide), in the rainy season. The $\mathrm{CO}_{2}$ and $\mathrm{CH}_{4}$ flux, mainly $\mathrm{CH}_{4}$ flux, in Mojuim River estuary was higher than that recorded in previous studies carried out in tropical regions, as shown in details below. Organic matter decomposition in the aquatic environment depends on a set of factors, including microbial community composition, ${ }^{39}$ redox state, and sorption/desorption of organic molecules on mineral surfaces. ${ }^{40,41}$ The release of $\mathrm{CO}_{2}$ dissolved in water released into the atmosphere can be influenced by greater agitation caused by tide moves. ${ }^{42}$ Carbon oxide flux in the study site, in the two evaluated seasons, was higher at the high tide than at the low tide - this outcome evidences that ocean water entrance in the estuary has strong influence on $\mathrm{CO}_{2}$ and $\mathrm{CH}_{4}$ flux. This seemed to have been the response to the difference in Tw and $\mathrm{S}$, as discussed below. However, $\mathrm{CH}_{4}$ flux in the dry season was higher at the flood tide, whereas, it was five times higher at the ebb tide, in the rainy period, as shown above.

The herein presented water physical-chemical parameters only concern the river, because the stream did not show water blade in the dry season, and also because one of the used devices was broken in the rainy season. The highest and lowest air thermal amplitudes were 
recorded at the flood tide, either in the dry or in the rainy season. Tar amplitude in the dry season was $2.00^{\circ} \mathrm{C}$, whereas it was $1.40^{\circ} \mathrm{C}$ in the rainy season. Tar was significantly higher at the flood tide than at the ebb tide $(\mathrm{LSD}=0.71, \mathrm{p}=0.03)$. On the other hand, Tw presented higher amplitude at the ebb tide $\left(1.05^{\circ} \mathrm{C}\right)$ and lower at the flood tide $\left(0.31^{\circ} \mathrm{C}\right)$, in the rainy season (Table 3$)$ - there was significant variation $(\mathrm{H}=5.224, \mathrm{p}=0.02)$ between tides only in the dry season.

Although water $\mathrm{pH}$ did not statistically vary between different tides, in the two seasons, it presented higher amplitude in the rainy season, mainly in the flood tide (Table 3). This profile may have resulted from river's photosynthetic activity increase due to consumption of $\mathrm{CO}_{2}$ dissolved in water, which shifts the balance of the carbonate system and, consequently, increases organic productivity. ${ }^{43,44}$ This result can be observed in DO saturation values, which have evidenced low saturation in the dry season $(10 \%-40 \%)$, whereas there was DO oversaturation $(78 \%-148 \%)$ in the rainy season. In addition, ORP values were positive ( 4.9 to $\left.6.9 \mathrm{mg} \mathrm{L}^{-1}\right)$ in the dry season and negative (-1.9 to $\left.2.8 \mathrm{mg} \mathrm{L}^{-1}\right)$ in the rainy season - this outcome is indicative of higher photosynthetic yield in the dry season. ORP and DO have shown significant differences between tide stages in the dry season $(\mathrm{ORP} ; \mathrm{LSD}=9.25 ; \mathrm{p}=0.002$ and $\mathrm{DO} ; \mathrm{LSD}=0.473 ; \mathrm{p}=0.000)$ higher values were recorded in the flood tide (Table 3 ).

$\mathrm{EC}$ and $\mathrm{S}$ recorded the highest values and amplitude in the dry season, when the influence of ocean water was more intense, as proven by the higher $\mathrm{S}$ values observed in this season (Table 3). However, when variations between tides were compared, EC (LSD $=1.05 ; \mathrm{p}=0.003)$ and $\mathrm{S}(\mathrm{LSD}=0.07 ; \mathrm{p}=0.007)$ were significantly higher at the ebb tide, in the rainy season. Although Tur was higher in the rainy season than in the dry one, there was no significant variation $(p>0.05)$ between tides in both seasons (Table 3).

Different from other studies performed in Eastern Amazonian estuary, ${ }^{45}$ we did not find significant Tur variation between tides (flood and ebb) either in the dry or in the rainy seasons. Pamplona et al. (2013) only found significant tide $\mathrm{pH}$ variation in the Amazonian estuary due to tides, but it was not observed in the current study. Taici bore (Bragança-PA, Brazil) did not show significant differences in physical-chemical parameters, although it presented different values between the ebb and flood tides, in the dry and rainy seasons. ${ }^{47}$

We have observed significant negative correlation between $\mathrm{CO}_{2}$ flux and variables EC (Pearson $=-0.88 ; \mathrm{p}=0.022$ ) and $\mathrm{S}$ (Pearson $=-0.902 ; \mathrm{p}=0.014)$ at the ebb tide in the rainy season. We have observed positive correlation between $\mathrm{CO}_{2}$ flux and $\mathrm{Tw}$ (Pearson = $0.77 ; \mathrm{p}=0.042)$ and $\mathrm{S}($ Pearson $=0.87 ; \mathrm{p}=0.011)$ at the flood tide. Tar presented negative correlation to $\mathrm{CO}_{2}$ flux (Pearson $=-0.77 ; \mathrm{p}=$ 0.041 ), but $\mathrm{CH}_{4}$ flux has significant negative correlation to $\mathrm{pH}$ (Pearson $=-0.91 ; \mathrm{p}=0.011)$ and $\mathrm{DO}($ Pearson $=-0.88 ; \mathrm{p}=0.006)$ in the rainy season, only at the ebb tide, consequently, they are important $\mathrm{CO}_{2}$ flux control factors. $\mathrm{CH}_{4}$ flux presented significant negative correlation to Tur at the flood tide in the dry season (Pearson $=-0.88 ; \mathrm{p}=0.010$ ).

Studies carried out in the Amazonian estuary have shown that DO concentrations were higher at the high tide and decreased as water level reduced in the dry season..$^{45} \mathrm{~A}$ set of previous research conducted in Australia have evidenced that $\mathrm{CO}_{2}$ concentration in water, in the dry and rainy seasons, was higher at the low tide than at the high tide, and that such a concentration was positively correlated to DO and $\mathrm{pH}^{38}$ Our results have shown positive correlation between $\mathrm{DO}$ and $\mathrm{CO}_{2}$ flux in the dry season, as well as negative correlation between $\mathrm{CH}_{4}$ flux and DO concentration in the same season. Streams are enriched by particulate organic carbon, dissolved organic carbon and dissolved inorganic carbon resulting from surface flow, sediment resuspension and, most of all, by groundwater discharge, at the ebb tide., ${ }^{6,1346}$ This higher carbon input could be observed through progressive higher $\mathrm{CO}_{2}$ flux in the stream at the ebb tide, during sampling throughout the dry season (Figure 3).

Our study has shown that $\mathrm{EC}$ and $\mathrm{S}$ were important for $\mathrm{CO}_{2}$ flux in the rainy season at the ebb tide, whereas we have observed Tw and $\mathrm{S}$ as the main $\mathrm{CO}_{2}$ flux at the flood tide. On the other hand, only Tar has influenced $\mathrm{CO}_{2}$ flux in the dry season at the flood tide..$^{39}$ Factors influencing $\mathrm{CO}_{2}$ and $\mathrm{CH}_{4}$ flux have varied due to tide height and seasonality, therefore, it is not possible stating that one important factor alone is relevant for $\mathrm{CO}_{2}$ and $\mathrm{CH}_{4}$ flux in the assessed macrotide estuary, but a combination of water chemistry factors related to tide move. Moreover, these factors can be different in each climatic period.

Our results agree with those obtained by Chuang ${ }^{29}$, there were no differences in $\mathrm{CO}_{2}$ and $\mathrm{CH}_{4}$ flux between assessed locations, both in the dry and rainy seasons, although $\mathrm{CO}_{2}$ flux was higher in the river and $\mathrm{CH}_{4}$ flux was higher in the stream (Figure 5). We have shown that the mean $\mathrm{CO}_{2}$ flux reached $450.9 \mathrm{mmol} \mathrm{m}^{-2}$ day $^{-1}$, was expressively higher than that recorded in other studies carried out in tropical areas (Borges et al., 2004; Linto et al., 2014; Rosentreter et al., 2018b; Taillardat et al., 2018a; Smith \&Atkinson, 1983, Bouillon et al., 2007; Kristensen et al., 2008; Ralison et al., 2008).$^{51}$ This outcome may have resulted from the high temperatures along the year, in combination to high concentrations of suspended and dissolved organic matter ${ }^{52}$ and nutrients dissolved in water. ${ }^{53}$ Similar to what we have found in other studies, $5^{4-56}$ there was huge seasonality in $\mathrm{CO}_{2}$ flux in Mojuim River estuary - flow is almost three times higher in the rainy season than in the dry period (Table 1).
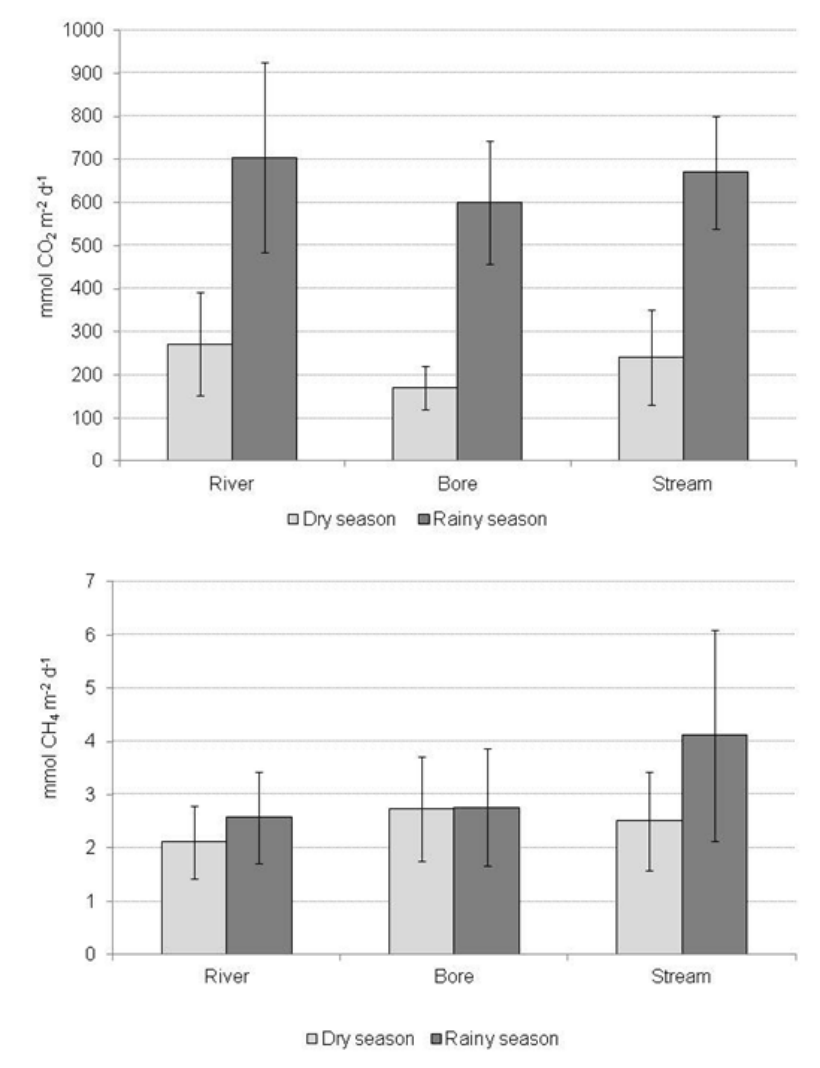

Figure $5 \mathrm{CO}_{2}$ and $\mathrm{CH}_{4}$ flux $\left(\mathrm{mmol} \mathrm{m} \mathrm{m}^{-2} \mathrm{~d}^{-1}\right)$ in the river, bore and stream, in the dry and rainy seasons, in Mojuim River estuary. The bars indicate the mean standard error. 
The marginal areas of Mojuim River are fully flooded in the lunar square period (spring tides, mainly in the equinox), and it resulted in higher rainy season flux. We have observed greater inorganic carbon input from the river to the estuary in the rainy season, in addition to soil leachate, which led to high $\mathrm{CO}_{2}$ flux into the atmosphere. ${ }^{50}$ Higher $\mathrm{CO}_{2}$ flux in the rainy season is likely a combination of carbon source from the mangrove and upstream areas, to mineral carbonate dissolution in the soil and groundwater. ${ }^{57,4}$ However, different from what was previously published, ${ }^{38}$ the higher concentration of $\mathrm{CO}_{2}$ dissolved in water in the dry season seemed not to result in $\mathrm{CO}_{2}$ output into the atmosphere in comparison to the rainy season (Figure 5).

$\mathrm{CO}_{2}$ flux was significantly correlated to $\mathrm{pH}($ Pearson $=-0.51 ; \mathrm{p}=$ $0.001)$, ORP $($ Pearson $=0.37 ; \mathrm{p}=0.025)$, TDS $($ Pearson $=0.36 ; \mathrm{p}=$ $0.032)$ and $S($ Pearson $=0.44 ; p=0.007)$ in the rainy season. However, it was not correlated to the assessed environmental variables in the dry season. Increased fluvial discharge in most Amazonian estuaries is observed in the rainy season and it reduces coastal water salinity in the region ${ }^{46}$ and makes water more alkaline and oxygenated, with higher concentrations of nutrients and chlorophyll. ${ }^{58,59}$ It is necessary having nitrogen input to achieve the decomposition of organic matter. Such a greater contribution was observed in a study conducted in the Amazonian estuary during the rainy season..$^{58}$

Mojuim River estuary has presented mean $\mathrm{CH}_{4}$ flux of $2.8 \mathrm{mmol}$ $\mathrm{m}^{-2}$ day $^{-1}$, which was numerically higher in the rainy season, however, it did not statistically differ ( $L S D=1.65 ; p=0.39$ ) from the dry season (Table 1). The few existing studies on this topics that have assessed water seasonality in $\mathrm{CH}_{4}$ flux between water and atmosphere have shown greater flux through the rainy season than in the dry season. ${ }^{59-62}$ Some studies carried out in the estuary have shown that $\mathrm{CH}_{4}$ concentrations in water are driven by different side entrances - it is possible having intense spatial and seasonal variability. ${ }^{63} \mathrm{We}$ did not measure $\mathrm{CH}_{4}$ concentration in estuary water, but if such a seasonal and spatial variation in the concentrations is actually real, it was not supported by gas flux.

Although $\mathrm{CH}_{4}$ flux did not show seasonal difference, it was correlated to $\mathrm{pH}($ Pearson $=-0.36 ; \mathrm{p}=0.030)$ and $\operatorname{Tur}($ Pearson $=0.41$; $\mathrm{p}=0.013)$ in the rainy season, and to $\mathrm{Tw}($ Pearson $=-0.427 ; \mathrm{p}=0.012)$ in the dry season. Physical processes such as temperature gradient and salinity, water depth and groundwater discharge mix, and microbial processes (like organic matter respiration rate) are factors controlling $\mathrm{CH}_{4}$ production and oxidation in estuaries. ${ }^{57}$ Between $50-90 \%$ of the methane produced in wet mangrove areas, strongly influenced by the tide, is oxidized upwards in sediment by methanotrophs before reaching the atmosphere. ${ }^{64,65}$ Accordingly, it seems that $\mathrm{CH}_{4}$ oxidation in the Mojuim River estuary was not enough to stop methane from escaping to the atmosphere, as observed by Chuang ${ }^{28}$. Our results have shown that $\mathrm{CH}_{4}$ flux was numerically higher in the stream than in the river, where one observes greater oceanic influence. Thus, $\mathrm{CH}_{4}$ production in estuaries often decreases as water flows to the ocean. This process is motivated by the action of sulfate-reducing bacteria, which surpass the methanogenic ones. ${ }^{66,67}$

Water temperature fluctuation affects $\mathrm{CO}_{2}$ solubility, ${ }^{7}$ primary production and organic carbon decomposition. ${ }^{68^{2}} \mathrm{Although} \mathrm{Tw}$ increase was not significant in all months in the dry season, temperature increase led to higher water $\mathrm{CO}_{2}$ flux into the atmosphere. However, the same finding was not observed in the rainy period (Table 2). Methane is the final product of organic material anaerobic decomposition by different microorganisms - methanogenic bacteria are much more reactive to temperature than methanotrophic bacteria $^{69}$ - and the ideal temperatures for $\mathrm{CH}_{4}$ production and oxidation are close to $25^{\circ} \mathrm{C}^{70} \mathrm{CH}_{4}$ flux in the dry season was negatively correlated to $\mathrm{Tw}$
(Pearson $=-0.427, \mathrm{p}=0.012$ ), in the present study. $\mathrm{CH}_{4}$ emissions are often reported to have linear or exponential relation to soil or water temperatures. ${ }^{70,71}$

$\mathrm{CO}_{2}$ and $\mathrm{CH}_{4}$ flux was negatively correlated to $\mathrm{pH}$ (Pearson = $-0.51, \mathrm{p}=0.001$, and Pearson $=-0.36, \mathrm{p}=0.030$, respectively) in the rainy season. The $\mathrm{pH}$ was below 6.0 only at the beginning of the rainy season (Table 2), it may be the consequence of free and dissolved $\mathrm{CO}_{2}$ reduced acidifying effect, as well as of the presence of organic acids transported to the estuary by rainwater. ${ }^{53}$ The $p \mathrm{CO}_{2}$ and $\mathrm{CO}_{2}$ flux is negatively correlated to $\mathrm{pH}$ in reservoir surface. ${ }^{72,73}$ Critical $\mathrm{pH}$ values between $\mathrm{CO}_{2}$ absorption and emission through water are often reported as 7.9 at 8.5 , respectively. ${ }^{74,75}$ Our results have shown that sometimes water becomes alkaline, either in the dry or in the rainy season (Table 2). Alkaline $\mathrm{pH}$ favors bicarbonate formation and promotes atmosphere $\mathrm{CO}_{2}$ absorption, ${ }^{76,75}$ however, $\mathrm{CO}_{2}$ production for the atmosphere was only observed during data collection.

Although DO was not correlated to $\mathrm{CO}_{2}$ production in the rainy season, increased DO concentration in water has reduced $\mathrm{CO}_{2}$ flux to the atmosphere - the same was not observed in the dry season. Based on such a finding, autotrophic organisms consume dissolved $\mathrm{CO}_{2}$ from the water column and produce oxygen in the rainy season ${ }^{21,71}$ - rain can oxygenate surface water. $\mathrm{CH}_{4}$ was not correlated to DO in water, but it was not observed between these two parameters in the two seasons, in any trend. The highest DO concentrations observed in the rainiest months have allowed classifying water in the Mojuim River estuary as saturated, however, it did not happen in the dry season (Table 2). Fluvial component and tide intensity in the rainy season produces mixtures through swirling in the dry season, when the fluvial component diminishes due to low precipitation - this process increases saline intrusion and makes water column slightly stratified. ${ }^{14}$ Such stratification can be important for the lowest $\mathrm{CO}_{2}$ flux in the dry season because the heaviest water column can retain gas in layers below the surface and reduce gas flux.

$\mathrm{CO}_{2}$ and $\mathrm{CH}_{4}$ flux between water and atmosphere in the estuary, as well as the flux of other gases, has passive diffusion and is the prevailing process ${ }^{38}$ However, there are other non-diffusible processes induced by subsurface entrainment, such as the flux of microbubbles formed in oversaturated environments. ${ }^{77,78}$ This process can influence gas flux. It was possible observing positive correlation between $\mathrm{CO}_{2}$ and $\mathrm{CH}_{4}$ flux (Pearson $=0.287, \mathrm{p}=0.001$ ), which suggests a common source of the both gases. A recent study ${ }^{38}$ has shown close association between ${ }^{222} \mathrm{Rn}$ and $\mathrm{CH}_{4}$ concentrations in the estuary, and this finding suggests the entrance of $\mathrm{CH}_{4}$ in highly enriched groundwater. This process induces the understanding of continental $\mathrm{CH}_{4}$ formation.

The gas concentration gradient between water and the atmosphere, as well as turbulent energy at the aqueous surface limit, are the two decisive factors for gas exchange between water and the atmosphere. ${ }^{79}$ $\mathrm{CO}_{2}$ concentration in water is driven by the consumption and production of autotrophic organisms and by the production of heterotrophic organisms, as well as by salinity, temperature and water alkalinity. ${ }^{51,80,81}$ However, lack of correlation between DO, and $\mathrm{CO}_{2}$ and $\mathrm{CH}_{4}$ flux, suggests no biological control over the flux of these two gases. DO concentration in water in low precipitation months (dry season) is very low, but in September it is above $5.0 \mathrm{mg} \mathrm{L}^{-1}$ (Table 2). DO in the rainy season, between March and May, is above $5.0 \mathrm{mg} \mathrm{L}^{-1}$, on average. The significant increase in $\mathrm{CO}_{2}$ flux between December and January could have been caused by organic matter input, given the start of the rainy season and the sudden drop in $\mathrm{pH}$ value (Table 2 and Figure 6). This process could have taken humic acids to the water and reduced $\mathrm{pH}$ values. It seems that $\mathrm{pH}$ can influence $\mathrm{CH}_{4}$ flux in the dry season and $\mathrm{CO}_{2}$ flux in the rainy season. 

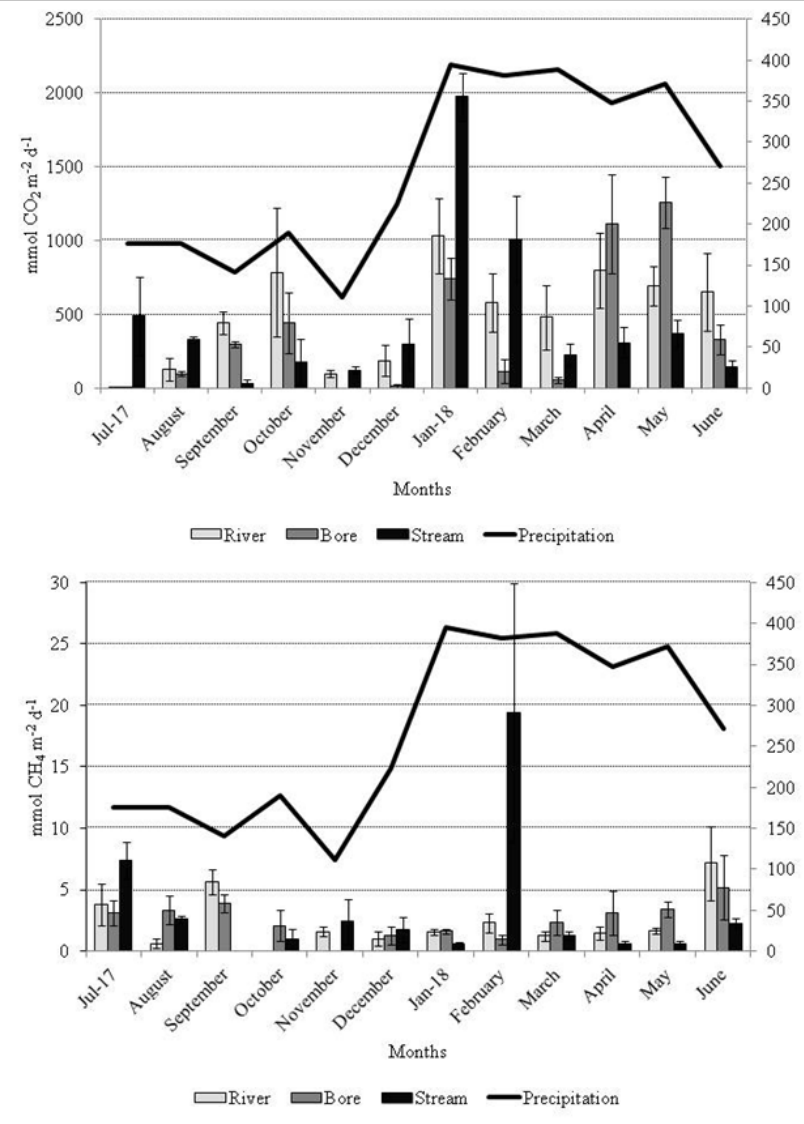

Figure $6 \mathrm{CO}_{2}$ and $\mathrm{CH}_{4}$ flux ( $\left.\mathrm{mmol} \mathrm{m}^{-2} \mathrm{~d}^{-1}\right)$ in the river, bore and stream, over a hydrological year in Mojuim estuary. The bars indicate the mean standard error.

\section{Conclusion}

We did not find any difference in $\mathrm{CO}_{2}$ flux between the ebb and flood tides, in the two assessed seasons. However, there was greater $\mathrm{CH}_{4}$ flux only at the ebb tide, in the rainy season. The flux of the two gases was significantly higher in the rainy season than in the dry season. There was mean annual $\mathrm{CO}_{2}$-e production of 542.5, 531.3, and $413.0 \mathrm{mmol} \mathrm{CO}_{2}-\mathrm{e} \mathrm{m}^{-2} \mathrm{~d}^{-1}$ in the river, stream and bore, respectively. $\mathrm{CO}_{2}$ and $\mathrm{CH}_{4}$ flux in this Amazonian mangrove area was higher than that in other tropical mangrove areas.

The compilation of several studies has shown that water $\mathrm{CO}_{2}$ flux in this tropical estuary area was $56.5 \pm 11.3 \mathrm{mmol} \mathrm{m}^{-2} \mathrm{~d}^{-1}$, on average. ${ }^{82,83}$ The only study ever published about the Amazonian mangrove area has shown mean $\mathrm{CO}_{2}$ flux of $173.7 \pm 57.8 \mathrm{mmol} \mathrm{m}^{-2} \mathrm{~d}^{-1} .^{13}$ The mean flux of $450.9 \pm 24.2 \mathrm{mmol} \mathrm{CO}_{2} \mathrm{~m}^{-2} \mathrm{~d}^{-1}$ found in the Mojuim river estuary were much greater than those presented in tropical estuaries.

With respect to water $\mathrm{CH}_{4}$ flux in tropical areas, it reached 0.2 $\pm 0.1 \mathrm{mmol} \mathrm{m}^{-2} \mathrm{~d}^{-1} .^{83,84,9,13} \mathrm{~A}$ corresponding study performed in the Amazonian mangrove area recorded $0.9 \pm 0.3 \mathrm{mmol} \mathrm{m}^{-2} \mathrm{~d}^{-1} \cdot{ }^{13}$ Our study showed that the average $\mathrm{CH}_{4}$ flux in the Mojuim River was $2.8 \pm 0.6 \mathrm{mmol} \mathrm{m}^{-2} \mathrm{~d}^{-1}$, that is, much higher than those presented in the literature. However, in tropical areas with climate Aw and Af the fluxes ranged from 0.35 to $5.41 \mathrm{mg} \mathrm{m}^{-2} \mathrm{~d}^{-1}, 85$ which is much higher than the $0.05 \mathrm{mg} \mathrm{m}^{-2} \mathrm{~d}^{-1}$ found in our study.

Carbon dioxide emissions in Mojuim River estuary were ten times higher than the $16.8 \mathrm{~mol} \mathrm{CO}_{2} \mathrm{~m}^{-2} \mathrm{yr}^{-1}$ recorded for subtropical and tropical estuaries ${ }^{86}$ Methane flux was almost four times higher in Mojuim River estuary than the $200 \mathrm{mmol} \mathrm{CH}_{4} \mathrm{~m}^{-2} \mathrm{yr}^{-1}$ estimated by Rosentreter ${ }^{18}$ and the $266 \mathrm{mmol} \mathrm{CH}_{4} \mathrm{~m}^{-2} \mathrm{yr}^{-1}$ estimated by Borges and Abril (2011). Accordingly, water $\mathrm{CO}_{2}$ and $\mathrm{CH}_{4}$ emissions in the mangrove area of the Amazonian biome are much higher than those recorded in other tropical areas. The annual estimate of water $\mathrm{CO}_{2}-\mathrm{e}$ production for the atmosphere was $3.35 \mathrm{Gg} \mathrm{CO}_{2}-\mathrm{e} \mathrm{yr}^{-1}$ when the area of the Mojuim River basin (45.5 ha) is taken into consideration. ${ }^{87-99}$

\section{Acknowledgments}

The authors are grateful to the Program of Alliances for Education and Training of the Organization of the American States and to Coimbra Group of Brazilian Universities, for the financial support, as well as to Paulo Sarmento for the assistance at laboratory analysis, and to Lucivaldo da Silva for the fieldwork assistance.

\section{Conflicts of interest}

The author declares there is no conflict of interest.

\section{References}

1. Rosentreter JA, Maher DTT, Erler DVV, et al. Factors controlling seasonal $\mathrm{CO} 2$ and $\mathrm{CH} 4$ emissions in three tropical mangrove-dominated estuaries in Australia. Estuar Coast Shelf Sci. 2018c;215:69-82.

2. Souza Filho PWM. Costa de manguezais de macromaré da Amazônia: cenários morfológicos, mapeamento e quantificação de áreas usando dados de sensores remotos. Rev Bras Geofísica. 2005;23:427-435.

3. Krause-Jensen D, Lavery P, Serrano O, et al. Sequestration of macroalgal carbon: the elephant in the Blue Carbon room. Biol Lett. 2018; 14:20180236.

4. Taillardat $P, Z$ iegler AD, Friess DA, et al. Carbon dynamics and inconstant porewater input in a mangrove tidal creek over contrasting seasons and tidal amplitudes. Geochim Cosmochim Acta. 2018b;237:32-48.

5. Li L, Barry DA, Stagnitti F, et al. Submarine groundwater discharge and associated chemical input to a coastal sea. Water Resour Res. 1999;35:3253-3259.

6. Stieglitz TC, Clark JF, Hancock GJ. The mangrove pump: The tidal flushing of animal burrows in a tropical mangrove forest determined from radionuclide budgets. Geochim Cosmochim Acta. 2003;102:12-22.

7. Bauer JE, Cai WJ, Raymond PA, et al. The changing carbon cycle of the coastal ocean. Nature. 2016;504:61-70.

8. Cui X, Liang J, Lu W. Stronger ecosystem carbon sequestration potential of mangrove wetlands with respect to terrestrial forests in subtropical China. Agric For Meteorol. 2018;249:71-80.

9. Ralison $\mathrm{OH}$, Borges AV, Dehairs F, et al. Carbon biogeochemistry of the Betsiboka estuary (north-western Madagascar). Org Geochem. 2008;39:1649-1658.

10. Ray R, Jana TK. Carbon sequestration by mangrove forest: One approach for managing carbon dioxide emission from coal-based power plant. Atmos Environ. 2017;171:149-154.

11. Chen CTA, Huang TH, Chen YC, et al. Air-sea exchanges of coin the world's coastal seas. Biogeosciences. 201;10:6509-6544.

12. Rosentreter JA, Maher DT, Erler DV, et al. Methane emissions partially offset "blue carbon" burial in mangroves. Sci Adv. 2018b;4:eaao4985.

13. Call M, Santos IR, Dittmar T, et al. High pore-water derived $\mathrm{CO}_{2}$ and $\mathrm{CH} 4$ emissions from a macro-tidal mangrove creek in the Amazon region. Geochim Cosmochim Acta. 2019;247:106-120.

14. Berrêdo JF, Costa ML, Progene M do PS. Efeitos das variações sazonais do clima tropical úmido sobre as águas e sedimentos de manguezais do estuário do rio Marapanim, costa nordeste do Estado do Pará. Acta Amaz. 2008;38:473-482. 
15. Peel MC, Finlayson BL, McMahon TA. Updated world map of the Köppen-Geiger climate classification. Hydrol Earth Syst Sci. 2007;11:1633-1644.

16. INMET. Série Histórica - Dados Mensais [WWW Document]. BDMEP Banco Dados Meteorológicos para Ensino e Pesqui. 2019.

17. Jacotot A, Marchand $\mathrm{C}$, Allenbach $\mathrm{M}$. Tidal variability of $\mathrm{CO}_{2}$ and $\mathrm{CH}_{4}$ emissions from the water column within a Rhizophora mangrove forest (New Caledonia). Sci Total Environ. 2018';631-632:334-340.

18. Berman ESF, Fladeland M, Liem J, et al. Greenhouse gas analyzer for measurements of carbon dioxide, methane, and water vapor aboard an unmanned aerial vehicle. Sensors Actuators B Chem. 2012;169:128135.

19. Frankignoulle M. Field measurements of air-sea CO, exchange'. Limnol Oceanogr. 1988;33:313-322.

20. Mannich M, Fernandes CVS, Bleninger TB. Uncertainty analysis of gas flux measurements at air-water interface using floating chambers. Ecohydrol Hydrobiol. 2019;19:475-486.

21. Kremer JN, Nixon SW, Buckley B, et al. Technical note: Conditions for using the floating chamber method to estimate air-water gas exchange. Estuaries. 2003;26:985-990.

22. Yang L, Lu F, Zhou X, et al. Progress in the studies on the greenhouse gas emissions from reservoirs. Acta Ecol Sin. 2014;34:204-212.

23. Zappa CJ, McGillis WR, Raymond PA, et al. Environmental turbulent mixing controls on air-water gas exchange in marine and aquatic systems. Geophys Res Lett. 2007;34: 1-6.

24. Lorke A, Bodmer P, Noss C, et al. Technical note: drifting versus anchored flux chambers for measuring greenhouse gas emissions from running waters. Biogeosciences. 2015;12:7013-7024.

25. Tokoro T, Watanabe A, Kayanne $\mathrm{H}$. Measurement of air-water $\mathrm{CO}_{2}$ transfer at four coastal sites using a chamber method. J Mar Syst. 2007;66:140-149.

26. Vachon D, Prairie YT, Cole JJ. The relationship between near-surface turbulence and gas transfer velocity in freshwater systems and its implications for floating chamber measurements of gas exchange. Limnol Oceanogr. 2010;55:1723-1732.

27. Guérin F, Abril G, Serça D, et al. Gas transfer velocities of $\mathrm{CO}_{2}$ and $\mathrm{CH}_{4}$ in a tropical reservoir and its river downstream. $J$ Mar Syst. 2007;66:161-172.

28. Chuang PC, Young MB, Dale AW, et al. Methane fluxes from tropical coastal lagoons surrounded by mangroves, Yucatán, Mexico. J Geophys Res Biogeosciences. 2017;122:1156-1174.

29. Souza AT De, Heldwein $\mathrm{AB}$, Streck NA, et al. Emissão de nós e rendimento de feijão-de-vagem cultivado em ambiente protegido e em ambiente externo. 2009;1.

30. Pinto TJ da S, Gomes BM. $\mathrm{CO}_{2}$ Flux and its Relationship with Water Parameters and Biological Activity in the Ji-Paraná River (Rondônia State - Western Amazon). Biogeosciences Discuss. 2017;1-14.

31. Borges AV, Abril G. Carbon Dioxide and Methane Dynamics in Estuaries. In: Treatise on Estuarine and Coastal Science. Elsevier Inc., 2011. p. 119-161.

32. Call M, Maher DT, Santos IR, et al. Spatial and temporal variability of carbon dioxide and methane fluxes over semi-diurnal and spring-neapspring timescales in a mangrove creek. Geochim. Cosmochim Acta. 2015;150:211-225.

33. Taillardat P, Friess DA, Lupascu,M. Mangrove blue carbon strategies for climate change mitigation are most effective at the national scale. Biol Lett. 2018a;14:20180251.

34. Kristensen E, Flindt M, Ulomi S, et al. Emission of $\mathrm{CO}_{2}$ and $\mathrm{CH} 4$ to the atmosphere by sediments and open waters in two Tanzanian mangrove forests. Mar Ecol Prog Ser. 2008;370:53-67.
35. Lundevall-Zara M, Lundevall-Zara E, Brüchert V. Sea-Air Exchange of Methane in Shallow Inshore Areas of the Baltic Sea. Front Mar Sci. 2021;8:1109.

36. Stamp I, Baird AJ, Heppell CM. The importance of ebullition as a mechanism of methane $\left(\mathrm{CH}_{4}\right)$ loss to the atmosphere in a northern peatland. Geophys Res Lett. 2003;40:2087-2090.

37. Sundqvist E, Vestin P, Crill P, et al. Short-term effects of thinning, clearcutting and stump harvesting on methane exchange in a boreal forest. Biogeosciences. 2014;11:6095-6105.

38. Rosentreter JA, Maher DT, Erler DVV. Seasonal and temporal $\mathrm{CO}_{2}$ dynamics in three tropical mangrove creeks - A revision of global mangrove $\mathrm{CO}_{2}$ emissions. Geochim Cosmochim Acta. 2018a;222:729745 .

39. Tsai CP, Huang CM, Yuan CS, et al. Seasonal and diurnal variations of greenhouse gas emissions from a saline mangrove constructed wetland by using an in situ continuous GHG monitoring system. Environ. $\mathrm{Sci}$ Pollut Res. 2020;27:15824-15834.

40. Dittmar T. Reasons Behind the Long-Term Stability of Dissolved Organic Matter, in: Biogeochemistry of Marine Dissolved Organic Matter. Academic Press, 2015. p. 369-388.

41. Neu V, Ward ND, Krusche AV, et al. Dissolved organic and inorganic carbon flow paths in an amazonian transitional forest. Front Mar Sci. 2016;3:1-15.

42. Striegl RG, Dornblaser MM, McDonald CP, et al. Carbon dioxide and methane emissions from the Yukon River system. Global Biogeochem. Cycles. 2012;26:1-11.

43. Cotovicz Junior LC. Concentrations and atmospheric exchanges of carbon dioxide ( $\left.\mathrm{CO}_{2}\right)$ and methane $\left(\mathrm{CH}_{3}\right)$ in a tropical eutrophic estuary (Guanabara Bay, RJ, Brazil). Université de Bordeaux. 2016.

44. Miao G, Noormets A, Domec JC, et al. Hydrology and microtopography control carbon dynamics in wetlands: Implications in partitioning ecosystem respiration in a coastal plain forested wetland. Agric For Meteorol. 2017;247:343-355.

45. Asp NE, Gomes VJC, Ogston A, et al. Sediment source, turbidity maximum, and implications for mud exchange between channel and mangroves in an Amazonian estuary. Ocean Dyn. 2016;66:285-297.

46. Pamplona FC, Paes ET, Nepomuceno A. Nutrient fluctuations in the Quatipuru river: A macrotidal estuarine mangrove system in the Brazilian Amazonian basin. Estuar. Coast Shelf Sci. 2003;133:273-284.

47. Moura HTG de S, Nunes ZMP. Seasonal Characterization of the Waters of the Estuarine System of the Caete (Braganca-Pa). Bol Do Inst Pesca. 2016;42:844-854

48. Sippo JZ, Maher DT, Tait DR, et al. Mangrove outwelling is a significant source of oceanic exchangeable organic carbon. Limnol. Oceanogr Lett. 2018;2:1-8.

49. Borges AV, Vanderborght JP, Schiettecatte LS. Variability of the gas transfer velocity of $\mathrm{CO}_{2}$ in a macrotidal estuary (the Scheldt). Estuaries. 2004;27:593-603.

50. Linto N, Barnes J, Ramachandran R, et al. Carbon Dioxide and Methane Emissions from Mangrove-Associated Waters of the Andaman Islands, Bay of Bengal. Estuaries and Coasts. 2014;37:381-398.

51. Borges AV, Abril G, Bouillon S. Carbon dynamics and $\mathrm{CO}_{2}$ and $\mathrm{CH} 4$ outgassing in the Mekong delta. Biogeosciences. 2018;15.

52. Valerio A de M, Kampel M, Vantrepotte V, et al. Using CDOM optical properties for estimating DOC concentrations and $\mathrm{pCO} 2$ in the Lower Amazon River. Opt Express. 2018;26(14):A657-A677.

53. Monteiro S de M, El-Robrini M, Alves ICC. Seasonal dynamics of nutrients in an Amazon estuary. Mercator. 2015;14:151-162.

54. Carini S, Weston N, Hopkinson C, et al. Gas Exchange Rates in the Parker River Estuary, Massachusetts. Biol Bull. 1996;191:333-334. 
55. Jiang LQ, Cai WJ, Wang Y. A comparative study of carbon dioxide degassing in river- and marine-dominated estuaries. Limnol Oceanogr. 2008;53:2603-2615.

56. Wanninkhof R. Relationship between wind speed and gas exchange over the ocean revisited. Limnol Oceanogr Methods. 2014;12:351-362.

57. Sadat-Noori M, Santos IR, Sanders CJ, et al. Groundwater discharge into an estuary using spatially distributed radon time series and radium isotopes. J Hydrol. 2015;528:703-719.

58. Costa ÁKR da, Pereira LCC, Costa RM da. Oceanographic processes in an Amazon estuary during an atypical rainy season. $J$ Coast Res. 2013;165:1104-1109.

59. Sousa NSS, Monteiro MC, Gorayeb A, et al. Effects of sewage on natural environments of the amazon region (Pará-Brazil. In: Journal of Coastal Research. Coastal Education Research Foundation Inc., 2016. p. 158-162.

60. Lekphet S, Nitisoravut S, Adsavakulchai S. Estimating methane emissions from mangrove area in Ranong Province, Thailand. Songklanakarin J Sci Technol. 2005;27:153-163.

61. Murray R, Erler D, Rosentreter J, et al. A seasonal source and sink of nitrous oxide in mangroves: Insights from concentration, isotope, and isotopomer measurements. Geochim Cosmochim Acta. 2018;238.

62. Upstill-Goddard RC, Salter ME, Mann PJ, et al. The riverine source of CH4 and $\mathrm{N} 2 \mathrm{O}$ from the Republic of Congo, western Congo Basin. Biogeosciences. 2017;14:2267-2281.

63. Nirmal Rajkumar A, Barnes J, Ramesh R, et al. Methane and nitrous oxide fluxes in the polluted Adyar River and estuary, SE India. Mar Pollut Bull. 2008;56:2043-2051.

64. Linhares D do C, Saia FT, Duarte RTD, et al. Methanotrophic Community Detected by DNA-SIP at Bertioga's Mangrove Area, Southeast Brazil. Microb Ecol. 2021;81:954-964.

65. Shiau YJ, Cai Y, Lin Y Te, et al. Community Structure of Active Aerobic Methanotrophs in Red Mangrove (Kandelia obovata) Soils Under Different Frequency of Tides. Microb Ecol. 2018;75:761-770.

66. Middelburg JJ, Nieuwenhuize J, Iversen N, et al. Methane distribution in European tidal estuaries. Biogeochemistry. 2002;59:95-119.

67. Valenzuela EI, Avendaño KA, Balagurusamy N, et al. Electron shuttling mediated by humic substances fuels anaerobic methane oxidation and carbon burial in wetland sediments. Sci Total Environ. 2019;650:26742684.

68. Lü Y, Liu C, Wang $\mathrm{S}$, et al. [Seasonal variability of $\mathrm{p}\left(\mathrm{CO}_{2}\right)$ in the two Karst reservoirs, Hongfeng and Baihua Lakes in Guizhou Province, China]. Huan jing ke xue= Huanjing kexue. 2007;28:2674-81.

69. Lessard R, Rochette P, Topp E, et al. Methane and carbon dioxide fluxes from poorly drained adjacent cultivated and forest sites. Can J Soil Sci. 1994;74:139-146.

70. Dunfield P, knowles R, Dumont R. Methane production and consumption in temperate and subarctic peat soils: Response to temperature and $\mathrm{pH}$. Soil Biol Biochem. 1993;25:321-326.

71. Hernández ME, Junca-Gómez D. Carbon stocks and greenhouse gas emissions $\left(\mathrm{CH}_{4}\right.$ and $\left.\mathrm{N}_{2} \mathrm{O}\right)$ in mangroves with different vegetation assemblies in the central coastal plain of Veracruz Mexico. Sci Total Environ. 2007;140276.

72. Peng $\mathrm{X}$, Wang $\mathrm{B}$, Liu C. Diurnal variations of $\mathrm{pCO}_{2}$ in relation to environmental factors in the cascade reservoirs along the Wujiang River, China. Chinese J Geochemistry. 2012;31:41-47.

73. Soumis N, Duchemin É, Canuel R, et al. Greenhouse gas emissions from reservoirs of the western United States. Global Biogeochem. Cycles. 2008; 18:n/a-n/a.
74. Akhand A, Chanda A, Watanabe K, et al. Reduction in Riverine Freshwater Supply Changes Inorganic and Organic Carbon Dynamics and Air-Water $\mathrm{CO}_{2}$ Fluxes in a Tropical Mangrove Dominated Estuary. $J$ Geophys Res Biogeosciences. 2021;126:e2020JG006144.

75. Tremblay A, Therrien J, Hamlin B. GHG Emissions from Boreal Reservoirs and Natural Aquatic Ecosystems. Springer, Berlin, Heidelberg, 2015. p. 209-232.

76. Kapsenberg L, Cyronak T. Ocean acidification refugia in variable environments. Glob Chang Biol. 2019;25:3201-3214.

77. McGinnis DF, Kirillin G, Tang KW, et al. Enhancing Surface Methane Fluxes from an Oligotrophic Lake: Exploring the Microbubble Hypothesis. Environ Sci Technol. 2015;49:873-880.

78. Prairie YT, del Giorgio PA. A new pathway of freshwater methane emissions and the putative importance of microbubbles. Inl Waters. 2013;3:311-320.

79. MacIntyre S, Jonsson A, Jansson M, et al. Buoyancy flux, turbulence, and the gas transfer coefficient in a stratified lake. Geophys. Res Lett. 2010;37:L24604.

80. Holmen K. The global carbon cycle. In: Butcher SS, et al., editors. Global Biogeochemical Cycles. Academic Press, San Diego, 1992. p. 239-262.

81. Soares DCE, Henry-Silva GG. Emission and absorption of greenhouse gases generated from marine shrimp production (Litopeneaus vannamei) in high salinity. J Clean Prod. 2019;218:367-376.

82. Borges AV, Delille B, Frankignoulle M. Budgeting sinks and sources of $\mathrm{CO}_{2}$ in the coastal ocean: Diversity of ecosystem counts. Geophys Res Lett. 2005;32:1-4.

83. Guo X, Dai M, Zhai W, et al. $\mathrm{CO}_{2}$ flux and seasonal variability in a large subtropical estuarine system, the Pearl River Estuary, China. J Geophys Res Biogeosciences. 2009;114.

84. Rao GD, Sarma VVSS. Variability in Concentrations and Fluxes of Methane in the Indian Estuaries. Estuaries and Coasts. 2005;39:16391650 .

85. Rosentreter JA, Borges AV, Deemer BR, et al. Half of global methane emissions come from highly variable aquatic ecosystem sources. Nat Geosci. 2021;144(14):225-230.

86. Akhand A, Chanda A, Manna S, et al. A comparison of $\mathrm{CO}_{2}$ dynamics and air-water fluxes in a river-dominated estuary and a mangrove-dominated marine estuary. Geophys Res Lett. 2016;43(22):11,726-11,735.

87. Costa MS, Rocha AS, Santos AS, et al. Influence of Tide on Salt Entrapment in the River Mojuim Estuary. J Coast Res. 2018;85:81-85.

88. Faber PA, Evrard V, Woodland RJ, et al. Pore-water exchange driven by tidal pumping causes alkalinity export in two intertidal inlets. Limnol. Oceanogr. 2014;59:1749-1763.

89. IPCC 2013. Climate change. The physical science basis, In: Stocker TF, et al., editors. Contribution of Working Group I to the Fifth Assessment Report of the Intergovernmental Panel on Climate Change 2013. Cambridge University Press, Cambridge, 2013. p. 1535.

90. Maher DT, Cowley K, Santos IR, et al. Methane and carbon dioxide dynamics in a subtropical estuary over a diel cycle: Insights from automated in situ radioactive and stable isotope measurements. Mar Chem. 2015;168:69-79.

91. Pereira LCC, da Costa, ÁKR da Costa, et al. Influence of a Drought Event on Hydrological Characteristics of a Small Estuary on the Amazon Mangrove Coast. Estuaries and Coasts. 2018;41:676-689.

92. Pereira LCC, Oliveira SMO de, Costa RM da. What happens on an equatorial beach on the Amazon coast when La Niña occurs during the rainy season? Estuar Coast Shelf Sci. 2013;135:116-127. 
93. Rosentreter JA, Maher DT, Ho DT, et al. Spatial and temporal variability of $\mathrm{CO}_{2}$ and $\mathrm{CH}_{4}$ gas transfer velocities and quantification of the $\mathrm{CH}_{4}$ microbubble flux in mangrove dominated estuaries. Limnol Oceanogr. 2017;62:561-578

94. Topp E, Pattey E. Soils as sources and sinks for atmospheric methane. In: Canadian Journal of Soil Science. NRC Research Press Ottawa, Canada, 1997. p. 167-178.

95. Yang WB, Yuan C, Huang B. Emission Characteristics of Greenhouse Gases and Their Correlation with Water Quality at an Estuarine Mangrove Ecosystem - the Application of an In-situ On-site NDIR Monitoring Technique. Wetlands. 2018;38:723-738.

96. Zhai W, Dai M, Guo X. Carbonate system and $\mathrm{CO}_{2}$ degassing fluxes in the inner estuary of Changjiang (Yangtze) River, China. Mar Chem. 2007; 107:342-356
97. Zhang G, Zhang J, Liu S, et al. Methane in the Changjiang (Yangtze River) Estuary and its adjacent marine area: Riverine input, sediment release and atmospheric fluxes. Biogeochemistry. 2008;91:71-84.

98. Zhao J, Malone SL, Oberbauer SF, et al. Intensified inundation shifts a freshwater wetland from a $\mathrm{CO}_{2}$ sink to a source. Glob Chang Biol. 2008;25:3319-3333.

99. Zhou H, Yin X, Yang Q. Distribution, source and flux of methane in the western Pearl River Estuary and northern South China Sea. Mar Chem. 2009; 117:21-31. 